\title{
Health, Healthcare and Nation-Building: \\ A Three-Dimensional Approach to Innovation in Canada
}

\author{
Glenn G. Brimacombe
}

The health and healthcare sector should be viewed not as a cost to be endured, but as an opportunity to be explored, embracing a vision for Canada to create the most innovative, high quality healthcare system committed to continuous quality improvement ... It should be the prime and prized example of innovation around the world. Implementing the vision of the health sector as an engine of economic growth will contribute greatly to a sustainable healthcare system.

- Roundtable on Canada's Knowledge Economy

New Models for Health Innovation, August 27, 2002

\section{INTRODUCTION}

Since the early to mid-1990s, Canadians have witnessed and participated in an emotion-laden debate about the future of health and healthcare. While the issues of timely access to a range of quality healthcare services framed the public policy discussion, a series of reports recommended the need to "reengineer" the architecture of the system and how it should be financed. ${ }^{1}$ It is important to understand that the health system is not a static structure, but a dynamic organism that should always be in search of more efficient and cost-effective means by which to organize and provide quality health services to Canadians on a timely basis.

Generally speaking, there is a broad consensus that the system as it is currently configured is "not sustainable" over the medium to long term. However, there still remain contentious policy discussions about the combination of specific initiatives that are required to place the health system on firmer ground now and into the future. At the heart of this policy discussion is how we can introduce a series of "innovations" into the Canadian health system in a way that closely mirrors the core values we hold as a country.

It is this notion of innovation in the health sector that is the focal point of this article. More particularly, while it is clear that a number of innovations have had a direct impact on improving the individual and collective health status of Canadians, and the manner in which patients navigate through the system and receive care, only recently has there been an increasing focus on the role of health innovation as a strategic policy instrument of sustainable economic development.

It needs to be clearly stated up front that introducing health innovation as a public policy instrument of sustainable economic prosperity and wealth generation should in no way suggest that the integrity of our health system - which is largely publicly funded and administered - will be undermined through increased "privatization." In fact, it is just the opposite: the public nature of our system provides Canada with a unique platform to leverage our investments in health discovery and innovation, while also ensuring that Canadian ideas generate added economic value at home.

1. Since the early 1990s, there have been three national reports (the National Forum on Health, the Royal Commission on the Future of Health Care in Canada and the Kirby Report), and all provinces with the exception of Manitoba have released major reports recommending changes to their health systems. 
Strictly from an economic viewpoint, investments in health innovation can bring with it new employment capacity, higher incomes, growing wealth and a robust tax base that would continue to reinvest in a range of social programs in Canada.

Thus, there are critical overarching policy questions to be asked: In which areas of health innovation does Canada currently have a global comparative advantage. Or: In which areas is Canada prepared to nurture a sector that will not only develop goods and services to be integrated into our health system, but also is a sector where Canada can compete in an increasingly interdependent and knowledge-based economy?

Generally speaking, the sectors that come to mind include the medical and assistive devices, biotechnology, health services, health informatics, medical imaging, biomolecular imaging, functional foods and nutraceuticals, and pharmaceuticals. In more specific terms, how do we maximize the potential of our investments in areas such as stem cell therapy, nanotechnology and our clinical trial capacity?

Understanding that there are many different "inputs" into the care-delivery process, in addition to maintaining and enhancing our health status, is Canada prepared to simply import what is needed - with scarce capital flowing out of the country? Or are we looking to invest in the infrastructure and mechanisms that are required to own the factors of production and capture the economic rent that can accrue from world-class, leading-edge innovations, while improving our quality of life? The challenge is expressed in this quote:

Among the many promising industrial subsectors subsumed within healthcare are information technology; biotechnology; health care diagnostic, treatment and delivery services; health care management; knowledge/information management systems (including data collection and software development); and imaging systems. These are also leadingedge sectors for employing our high-level human capital and talent, an essential requisite if we wish to become a knowledge-based economy and society. However, there is much more at stake here than merely missing out on a major export platform in the information era: Failure to be in the forefront of these remarkable diagnostic, treatment and servicedelivery innovations will mean that we will assuredly fail in our objective to ensure that Canadians will have access to state-of-the-art health care (Courchene 2003).

\section{The Three Dimensions of Health Innovation}

As the title of the article suggests, there are (at least) three over arching interconnected dimensions that capture the spectrum of health innovation. Importantly, they should be viewed as complementary and mutually reinforcing public policy objectives:
1. Innovations that are intended to improve our individual and collective health status such as public health measures, the introduction of laws governing safety helmets, cleaner environment and assistive medical devices.

2. Innovations that are designed to improve the delivery structure of the health system and the provision of a range of costeffective services on a timely basis such as regionalized health systems, care pathways, primary healthcare reform and patient safety measures.

3. Leading-edge, world-class, breakthrough innovations that provide opportunities to leverage major economic benefit as well as health gains.

\section{The National Policy Context for Health INNOVATION}

If health innovation can be generally defined within the three related components of health, healthcare and nation-building, it is fair to say that most of the country's focus has been on the first two elements, with less attention to the third. Not unexpectedly, one might expect this given the nature of the public policy debate that has unfolded over the past decade. There is an emerging recognition of the need to focus on the relationship between investing in health and healthcare, and how health innovation can contribute to our economic competitiveness and productivity as a nation.

In the 2004 Speech from the Throne, the federal government recognized the relationship between innovation and economic development:

"Canada must now elevate its economic performance to the next level. Advancing technology and pervasive global competition demand of Canada a commitment to excellence, the pursuit of greater productivity, and a vision directed outward to the challenges and opportunities the world presents... The next challenge is to turn more of Canadians' bright ideas into dynamic businesses, great jobs and growing export earnings." (Speech from the Throne 2004)

More recently, the First Ministers' Ten-Year Plan to Strengthen Health Care identified the role of health innovation, competitiveness and productivity: "A strong, modern health care system is a cornerstone of a healthy economy. Investments in health system innovation through science, technology and research help to strengthen health care as well as our competitiveness and productivity" (A Ten-Year Plan 2004).

If we are to take full advantage of our collective health innovation potential in terms of what we have to offer Canadians through our health system and the rest of the world, we need to ensure that we have a sound and vibrant public policy framework that supports these objectives. When it comes to strategic and targeted investments in support of advancing 
Canada's health innovation enterprise, the federal government has introduced a series of interlocking policy measures over the past few years. Specifically, from 1997 to 2005, the government introduced these initiatives:

- Annual funding for the Canadian Institutes of Health Research (CIHR) was established with annual funding at \$694 million in 2005 - and its base will increase by an additional $\$ 160$ million over the next five years.

- Genome Canada, created in 2000, has received \$375 million from the federal government and an additional \$225 million has been committed in the last two budgets.

- The Networks Centres of Excellence (NCE) was established as a permanent program in 1997 and has total funding of $\$ 77.4$ million.

- The Canada Research Chairs (CRC) provides $\$ 900$ million for 2,000 research professorships.

- The Canada Foundation for Innovation (CFI) was established with an endowment of $\$ 3.65$ billion in 1997. In 2003, CFI also received funding for a $\$ 500$ million Research Hospital Fund.

- The Medical and Related Sciences Project (MaRS) received $\$ 20$ million, designed to fuel the commercialization of health research.

- The Indirect Costs (IC) program in support of federal research was created. Funding for the program now stands at $\$ 245$ million and will increase to $\$ 320$ million by 2009 .

- $\$ 50$ million (over five years) has been set aside in a commercialization funds initiative designed to fund pilot projects and strengthen the commercialization activity of research hospitals and universities.

- The Business Development Bank of Canada received \$250 million, with $\$ 100$ million earmarked for pre-seed and seed investment to nurture the development of embryonic technologies in the areas including life sciences, biotechnology, medical technologies, environmental technologies and information/telecommunication technologies.

Combined, these measures support a number of components of the heath innovation value chain such as basic and applied research, infrastructure, technology transfer mechanisms and early-stage financing. All of these play an essential role in strengthening our collective capacity by helping to accelerate the discovery process and the development of innovative goods and services from the health sector.

Clearly, these investments are significant, and we should applaud the federal government for their wisdom and foresight to (continue to) invest in a number of pieces of an interlocking puzzle that support and nurture health innovation in Canada. That said, there is still discussion about how the federal government can assist in the acceleration of translating new ideas from the health sector into goods and services competing in the marketplace. At the end of the day, we must ensure that all components of the health research enterprise are structurally sound, effectively aligned and well resourced.

\section{What IS THE Size OF THE OPPORTUNITY?}

According to the most recent information, the global market for goods and services produced by the health sector is $\$ 1$ trillion and growing. Currently, Canada consumes about $2 \%$ of the global market and exports about $1 \%$. In comparison, the United Kingdom consumes about $3 \%$ of the global market and exports about 6\% (Frost \& Sullivan 2003).

Each year, Canada invests more than $\$ 2$ billion in a number of substantial and successful health related research and development activities - and allocates more than $\$ 120$ billion to the health system. Over the next decade, we can expect that in excess of $\$ 1.2$ trillion dollars will be invested in our health system. Given the substantial resources that are being invested in the health and healthcare of Canadians, how can we ensure that we maximize not only the health benefits but the "economic dividend" that can accrue to individuals and to the country as a whole? Just think that if we could double our exports from 1 to $2 \%$, the country would receive an additional $\$ 100$ billion in revenue!

Consider the words of the Honourable Paul Martin:

Today we spend more than $\$ 112$ billion every year on health care in this country - almost $10 \%$ of our GDP. But we buy most of our medical products and equipment from abroad. In fact, the sector represents one of our largest trade deficits - some $\$ 6$ billion a year and growing rapidly. Canada can do so much better than that. The fact is that there is an enormous - and growing - worldwide market for these products and services. And Canada is ideally positioned to capture a substantial share. (Martin 2003)

Thus, two of the policy decisions we need to consider include: Do we want to "make" or "buy" more of the goods and services produced by the health sector? How can Canada move from being more a "price taker" to being more a "price maker"?

\section{THE HIC PRoposal}

Canada has a strong foundation for capitalizing on global opportunities in the health sector. These include the "Canadian advantage" - the buying power, values and information advantages associated with our cherished publicly funded health system. We also have an excellent educational system in all of the basic, applied, engineering, software, business, social sciences and the health professions, and highly motivated scientists and researchers in all regions of the country who are already engaged in groundbreaking health discoveries. 
While current investments nurture the research and innovation enterprise in Canada, there is a concern that there exists an "innovation gap" between the discovery and development of innovative goods and services and the ability to effectively leverage their full economic value through the process of commercialization, so they can compete not only in Canada but also in the global marketplace. Some areas require further strengthening:

- expertise to identify commercial opportunities

- expertise regarding the application development of business plans/market analysis

- intellectual property expertise

- resources supporting industry-related real technology transfer expertise

- entrepreneurial management expertise

- access to testing infrastructure services

- availability of funding for proof-of-principle (both scientific and commercial)

- the ability to move quickly where time to market is a critical competitive element

- lack of focal point for investors

- access to domestic market to establish a track record as a basis for export

- development of necessary partnerships to market goods and services globally

The mission of the HIC model is to provide the vision, leadership and resources to transform Canada's healthcare sector by building on the "Canadian advantage" - our publicly-funded and internationally respected health system - to create a globally competitive health industry capable of developing and delivering world-class innovative products and services. ${ }^{2}$

The focus of HIC is twofold: (1) to build capacity that supports the commercialization of health products and services; (2) to provide direct pubic and private sector investment for early-stage commercialization initiatives. The HIC model identified three critical gaps for concerted action to measurably accelerate Canada's commercialization performance and catalyze the continued flow of new ideas and innovations:

\section{Early-Stage Financing to Boost Small, Innovative Firms}

The HIC model proposes a series of early-stage investment funds, which would be matched (at least) by private investors. These funds, managed by experts, would focus on areas that are of the highest risk, in effect chokepoints in the system such as proof-of-concept, detailed marketing assessments and business planning, and early-stage external financing. In some ways, the funds can be thought of as being more like angel funds rather than traditional venture capital funds.

\section{Hands-On Help to Leverage Hospital-Centred Innovation}

The HIC model also proposes to invest in a number of health innovation/commercialization centres located at, and in voluntary partnership with, teaching hospitals and regional health authorities. In effect, this is to build "receptor capacity," where much of the process of research and medical discovery occurs. HIC would finance the setup costs and part of the yearly costs of the health innovation/commercialization centres. This component would also see investment in business support and mentoring measures focused on health innovation and commercialization processes.

\section{Commercialization Platforms to Build National Linkages and Critical Mass}

The third piece would take full advantage of our universal, publicly funded health system by establishing more effective linkages and shared technology platforms, for example, more effective database linkages. HIC proposed investing in networking capabilities to more effectively link players in the Canadian health industry. If the legitimate concerns about privacy and informed consent can be addressed and incentives offered for data standardization, Canada has the opportunity to develop a globally unparalleled resource to support research and innovation.

In addition, funding would be sought to develop, and where required, repatriate those who have (or will have) experience in scientific and commercial knowledge with experience in commercialization.

Given the rapid developments in the biotechnology and information sciences, coupled with the aging demography of Canada, this will be an era of sustained growth in the health sector for decades to come. Globally, the sector is growing at $8 \%$ - more than five times as fast as the population.

With the measures proposed by the HIC model to advance leading-edge health products, services and technologies, the sector can help build Canada's 21st century economy. But the gains are not just economic. The success of the HIC model can help strengthen the stewardship of our treasured public health system and place Canada at the forefront of global health issues.

Finally, the HIC model believes that any actions must be voluntary and based on incentives. In unleashing latent innovation in the health sector, HIC will move in the most constructive fashion possible that supports the fundamental principles that underpin the Canada Health Act and the roles and responsibilities of the provinces.

2. For more details about the Health Innovation Canada (HIC) model, please go to www.msfhr.org/sub-strategic-national.htm. 


\section{Where Do We Go from Here?}

Interestingly, while a number of themes related to (health) innovation were identified in the federal government's recent 2005 Budget, few specifics focused on how we can more effectively harness and translate innovations from the health sector. Thus, the critical policy question is this: Where do we go from here?

In addition to the HIC model, it is important to note that there are other proposals that focus on innovation and commercialization in the health sector. Interestingly, there appears to be convergence among the proposals with regard to the diagnosis - that Canada is facing an innovation gap - and are similar in terms of the identified elements that need to be addressed.

At the same time, it appears that the federal government is looking for a sharper series of metrics that can more clearly articulate "the rate of return" that its investments are generating. This is an important point given the lack of consensus about how to measure return on investment - clearly more work must be done in this area. $^{3}$

In addition, as we continue to discuss how best to move forward in this area, it will be essential to develop a transparent and inclusive process that enables the health community to more effectively form a consensus. To this end, one proposal that has been tabled is the creation of a Canadian Health Industries Partnership (CHIP) model. As well, the Public Policy Forum will be hosting a conference on "Creating a Multi-Stakeholder Partnership in Support of Canada's Innovative Health Industries," April 26-27, 2005.4

\section{CONCLUSION}

As Lee Iacocca has said, "you can either lead, follow, or get out of the way." While there is a growing consensus that Canada should lead in the acceleration of health innovation and commercialization, now is the time to focus on the specific public policy instruments that can be introduced to maximize the social and economic rate of return that can accrue to the country as a whole. By so doing, we have the possibility of meeting four important objectives concurrently: (1) improving the health status and quality of life for Canadians; (2) building a health system that is flexible, responsive and cost-effective; (3) continuing to build the foundation of a truly modern 21 st century economy; (4) positioning Canada as a global leader. IQQ

\section{References}

"A Ten-Year Plan to Strengthen Health Care." 2004, September. First Ministers' Meeting. Courchene, T.J. 2003. Medicare as a Moral Enterprise: The Romanow and Kirby Perspectives (p. 12). Institute for Research on Public Policy.

Frost \& Sullivan - Growth Consulting. 2003. www.frost.com

Martin, P. 2003, September 18. Excerpt of Speech to Montreal Board of Trade.

Speech from the Throne. 2004, October 5. Office of the Prime Minister. Retrieved April 14, 2005. <www.pm.gc.ca/eng/sft-ddt.asp>.

\section{About the Author}

Glenn G. Brimacombe is the Chief Executive Officer of the Association of Canadian Academic Healthcare Organizations (ACAHO). Email contact: brimacombe@ acaho.org

3. Note that the Canadian Institutes of Health Research (CIHR) is embarking on a process to develop a methodology to assess return on investment, as is the Council of Academic Hospitals of Ontario (CAHO).

4. A summary of the Conference should be available on the public Policy Forum's Website at www.ppforum.ca.
Sticking to the Knitting: ClHR, Innovation and Canadian Biotech

\author{
Jeff Edelson
}

\begin{abstract}
The novel proposal outlined by Glenn Brimacombe suggests that the federal government directly participate in funding incremental venture capital investment in Canadian biotechnology, with the goal of facilitating commercialization of Canadian biotechnology and health sciences intellectual property. In this way, they suggest, the economic development benefits of the Canadian current investment in health sciences will be increased.
\end{abstract}

The proposal is based on two premises that need further evaluation: (1) the biotechnology sector in Canada presently underperforms in terms of value creation; (2) this underperformance is due to inadequate venture capital investment.

It is the author's view that, although several measures do suggest relative system underperformance, this is likely due to structural differences rather than inadequate venture capital investment. The absence of large, integrated, global biopharmaceutical firms based in Canada, the large number of very small biotech firms and the absence of a clear federal policy mandate supporting technology transfer and underinvestment in public sector funded basic research may all be contributory factors.

Given the Canadian biotech sector's current efficiency at creating value from limited public investment in basic science, increasing the core CIHR budget might be an even better investment opportunity for limited incremental funding. 


\section{INTRODUCTION}

"For upon every invention of value, we erect a statue to the inventor, and give him a liberal and honourable reward....

"Lastly, we have circuits or visits of divers principal cities of the kingdom; where, as it cometh to pass, we do publish such new profitable inventions as we think good." (Francis Bacon 1909-1914: para 88, 90)

Over 400 years ago, Francis Bacon identified commercialization of scientific discovery as an integral component of the process of innovation. His thoughts on the organization of an ideal research enterprise and its responsibilities to the public sector directly informed the development of the British Royal Society and many other research organizations to follow.

After a thorough consultative process, Brimacombe has thoughtfully framed the discussion in the current Canadian context. The resulting proposal would (a) develop a series of partnered public/private venture capital funds, with a total pool of approximately $\$ 800$ million, specializing in distinct areas of health sciences and biotechnology, (b) catalyze regional development of five prototypical health commercialization/innovation centres located at, and in partnership with, large teaching hospitals/health authorities and (c) (in the least well-defined aspect of the proposal) to promote development of several unique commercialization platforms including national standards for networking of health information, a national tissue banking capability and selective recruitment of key talent.

The first aspect of the proposal, designed to augment earlystage capital for "firms" to progress early-stage projects appears to assume that (a) the Canadian biotechnology space performs poorly and (b) that this poor performance is tied to a shortage of early-stage venture capital. Although some data support the first of these theses, available data suggest the second to be incorrect.

\section{QuestiON 1: Does Canadian Biotech Underperform in Terms of Value Creation? Revenue Generation}

Available data suggest several, albeit imperfect, means of assessing the fiscal performance of the Canadian biotech sector. One method is to compare the revenue generated by the sector (adjusted for various denominators - e.g., GDP, per capita) between Canada and other nations. This snapshot approach suggests that current revenue generated by Canadian biotechnology companies is approximately half that of US companies after adjustment either for total GDP or for total population (see Table 1).

\section{IP Production}

A prior analysis of Canadian patents filed in the US demonstrate Canadian patent productivity per capita suggest that, as of 1997 ,
Canadian per capita patent productivity was approximately onethird lower than that of the US, although growing at a slightly faster rate -6.4 versus 5.2\% (Trajtenberg 1999). The proportion of patents pertaining to the drugs and medical sector appear similar in Canada and the US. Ownership is also a potential challenge, with a much higher rate of Canadian patents apparently owned by foreign inventors - Canada $19 \%$ vs. USA $2 \%$ (Trajtenberg 1999). The author is not aware of more recent data that inform this question.

\section{Job Production}

In 2002, the Canadian biotechnology sector employed some 7,785 people. When normalized to either population or GDP, the Canada biotech sector produces approximately half the number of jobs in the comparable US sector.

\section{QUESTION 2: Is the Underperformance of the Canadian Biotech Sector due to Lack of Venture Capital Funding?}

Assuming that the Canadian biotechnology sector underperforms its southern neighbour in terms of job and revenue generation, and perhaps intellectual property production, it is not clear, however, that this is due to unique capital constraints in the Canadian environment. First, available data do not demonstrate significant, proportional differences between the two countries in availability of biotech funding. Second, there are a variety of other structural differences between the Canadian and US biotech environments that are more likely to influence system performance.

\section{Venture Capital Funding}

Several caveats apply to attempts to draw correlations between current private or public sector funding and biotech productivity. These include (a) the lengthy (7-12 year) product cycle development time, (b) extreme variability in the timing at which a product or portfolio may be capitalized (due to differences in market conditions, corporate strategy) and (c) the potential for local or temporal market inefficiencies. At any given time, the market may significantly under or undervalue any enterprise.

Notwithstanding these caveats and recent dramatic swings in the general availability of venture capital funding, data demonstrate new venture capital disbursements in 2002 (adjusted for GDP) are similar in the US and Canada, comprising approximately one quarter of $1 \%$ of GDP. Although similar, the proportion of funding targeting health sciences projects is slightly greater in the US (US 32\% versus Canada 26\%).

Relative underperformance of the Canadian biotechnology system is once again suggested by its relative difficulty in translating venture capital disbursements into biotech revenue, where it appears to be about $50 \%$ as effective as the US (see Table 1). 
Table 1.

\begin{tabular}{|c|c|c|c|}
\hline & USA (1) & Canada (2) & Reference/notes \\
\hline Population & $290,342,554$ & $32,207,113$ & $\begin{array}{l}\text { The World Factbook. 2003. Washington, D.C.: Central } \\
\text { Intelligence Agency. Retrieved May 12, } 2005 . \\
<\text { www.cia.gov/cia/publications/factbook/geos/ } \\
\text { us.html\#Econ>. }\end{array}$ \\
\hline GDP & \$10.98 trillion & \$957.7 billion & $\begin{array}{l}\text { The World Factbook. 2003. Washington, D.C.: Central } \\
\text { Intelligence Agency. Retrieved May 12, } 2005 . \\
<\text { www.cia.gov/cia/publications/factbook/geos/ } \\
\text { us.html\#Econ>. }\end{array}$ \\
\hline NIH/CIHR FY 2004 budget & $\$ 27,900$ million & $\$ 662$ million & $\begin{array}{l}\text { (1) http://www.aaas.org/spp/rd/nih04p.pdf } \\
\text { (2) http://www.cihr-irsc.gc.ca/e/21606.html }\end{array}$ \\
\hline NIH/CIHR budget/pop & $\$ 96.1$ (USD) & $\$ 20.5$ & Not currency adjusted \\
\hline $\mathrm{NIH} / \mathrm{CIHR}$ budget/GDP & $.254 \%$ & $.069 \%$ & Not currency adjusted \\
\hline 2002 Biotech revenue & 30,266 million & 1,466 million & $\begin{array}{l}\text { Ernst and Young. 2003. Beyond Borders. } \\
\text { The Global Biotechnology Report. <ww.ey.com> }\end{array}$ \\
\hline 2002 Biotech employment & 142,900 & 7,785 & $\begin{array}{l}\text { Ernst and Young. 2003. Beyond Borders. } \\
\text { The Global Biotechnology Report. <www.ey.com>. }\end{array}$ \\
\hline Biotech revenue per employee & $\$ 211,798$ & $\$ 188,310$ & \\
\hline Biotech revenue per GDP & $.27 \%$ & $.153 \%$ & \\
\hline Biotech revenue per population & $\$ 104.25$ & $\$ 45.51$ & \\
\hline $\begin{array}{l}\text { Biotech revenue per } \\
\mathrm{NIH} / \mathrm{MRC} \text { dollar }\end{array}$ & $\$ 1.08$ & $\$ 2.2$ & \\
\hline $\begin{array}{l}\text { Total venture capital } \\
\text { disbursed } 2002\end{array}$ & $\$ 24,200$ million & $\$ 2,500$ million & Macdonald \& Associates Limited. <www.cvca.ca>. \\
\hline $\begin{array}{l}\text { Total venture capital } \\
\text { disbursed per GDP }\end{array}$ & $.22 \%$ & $.26 \%$ & \\
\hline $\begin{array}{l}\text { Biotech revenue/ } \\
\text { venture capital disbursed }\end{array}$ & $\$ 1.250$ & $\$ .586$ & \\
\hline $\begin{array}{l}\text { Health sciences share of } \\
\text { venture capital disbursement }\end{array}$ & $32 \%$ & $26 \%$ & Macdonald \& Associates Limited. <www.cvca.ca >. \\
\hline Number of firms & 1,466 & 417 & $\begin{array}{l}\text { Ernst and Young. 2003. Beyond Borders. The Global } \\
\text { Biotechnology Report. <www.ey.com>. }\end{array}$ \\
\hline$\%$ public & $21.7 \%$ & $20.3 \%$ & \\
\hline Number of firms per GDP & .134 & .430 & Firms/billion dollars GDP \\
\hline
\end{tabular}

\section{Structural Differences}

Major structural differences between Canadian and US biotech sectors are (a) the absence of large, integrated global biopharmaceutical firms based in Canada, (b) the relatively high number of small firms in Canada, (c) the absence of clear federal policies promoting technology transfer and (d) severe underfunding of public sector supported basic research.

Although one can challenge the hypothesis that larger biopharmaceutical firms with existing marketed products drive a greater proportion of value creation than their smaller counterparts, they bring unquestionable value in terms of human capital. Given the critical need to assemble complex, multidisciplinary teams and the expertise needed for successful drug development, Canada may be relatively disadvantaged by not having ready access to big biopharma as a source of intellectual capital. An additional benefit of accessibility to larger development organizations is to provide access to an outsourcing market for small firms with projects at a range of development stages. To some extent, the second facet of the CIHR proposal, focused on regional centres of expertise may help in mitigating these challenges.

A second striking feature of the Canadian biotech environment is the relatively large number of small firms. Adjusted for GDP, Canada has nearly four times as many biotech firms as the US. The mean income of the US firms is US\$20.6 million versus $\mathrm{C} \$ 3.5$ million for the Canadian firms. Given 
that the productivity of Canadian biotech employees is similar to their US counterparts (C $\$ 188,310$ of revenue per Canadian employee versus US $\$ 211,798$ per US employee), it appears that significant consolidation may be a near-term feature of the Canadian biotech environment.

Government policies regarding the treatment of intellectual property represent a third major area of distinction between the US and Canada that may be reflected in differences in system performance. The public policy foundation informing the treatment of intellectual property in the US includes the Bayh-Dole Act of 1980 and the StevensonWydler Technology Innovation Act of 1980, which address publicly funded and federally conducted research respectively. The Bayh-Dole Act provides a clear mechanism whereby universities and government funding agencies enter into a funding agreement, granting rights of ownership to the university. The university must fulfill several obligations pertaining to disclosure of the invention, election whether to retain title, royalty sharing and preference to small businesses and US-based industry for its development. Universities, which can enter into exclusive licensing agreements with commercial firms have variously developed and exploited expertise in technology transfer. Although the Bayh-Dole and Stevenson-Wydler Acts are generally credited with enabling or accelerating commercialization of discoveries from US federally funded programs, some aspects of their implementation have been recently challenged. The US NIH has placed a moratorium on external consulting agreements of federal employees and the private sector, and announced a review of its conflict-of-interest policies (Weiss 2004). It will be interesting to see how Canada develops and implements relevant policy given its less standardized approach to technology transfer. (See Clarke 2000.)

One of the clearest distinctions, however, between the US and Canadian biotechnology environments is the degree of public investment in basic, hypothesis-driven research. Either as a fraction of GDP or per capita, the NIH outspends the CIHR on basic research by a factor of four to one. Notwithstanding significant differences in their scopes of enterprise, presence of in-house research centres and extra-mural overhead policies, this is a system input that may explain much of the performance difference between the two sectors. In fact, perhaps due in part to severe underinvestment in basic research, and despite its apparent inefficiency, the ratio of biotech revenue per NIH or CIHR dollar invested is approximately two fold higher in Canada than in the US.

\section{StICKING to THE KNITTING}

In the absence of a demonstrated proportionate lack of appropriate venture capital investment, and given the apparent inefficiency of the Canadian biotech sector, increased public sector investment (with private sector matching) into venture capital funding may not be the most efficient use of limited public funds. (In fact, given the relatively large number of existing Canadian biotech firms, one wonders if this might simply postpone eventual consolidation that might improve system efficiency.)

The CIHR might best focus on more traditional investment opportunities: (a) increasing public spending to support peerreviewed, investigator-initiated research and (b) continuing to provide judicious guidance and leadership regarding development of federal research-related policy. IQQ

\section{References:}

Bernstein, A. 2004, March. Message from President of CIHR on Federal Budget 2004. Canadian Institute of Health Research. Retrieved May 12, 2005. <www.cihr-irsc.gc.ca/e/about/21606.shtml>.

Christie, A.F., S. D’Aloisio, K.L. Gaita, M.J. Howlett and E.M. Webster. 2003. Analysis of the Legal Framework for Patent Ownership in Publicly Funded Research Institutions. Canberra, Australia: Department of Education Science and Training, Australian Government. Retrieved May 12, 2005. <www.dest.gov.au/sectors/ research_sector/publications_resources/other_publications/patent_own ership_in_publicly_funded_research_institutions.htm >.

Clarke, T.E. 2000, February. "Why Canada Needs a Technology Transfer Act.” Executive Summary. Revised 2001, November. Stargate Consultants Limited. Retrieved May 12, 2005. <http://www.stargateconsultants.ca/ttwebex.htm>.

Federal Laboratory Consortium for Technology Transfer. Using Cooperative Research and Development Agreements (CRDAs). <www.federallabs.org/servlet/newContentObjServlet?LinkCoArID=19 99-03-29-15-24-58-800-eportney\&CoArRegion=National\&parentID =1999-03-29-15-21-01-910-eportney>.

Fitzgerald, M. 2004, May 1. Special Report: Entrepreneurs Emerge From Winter Thaw. Venture Capital Journal. New York: Thomson. Retrieved May 12, 2005. <ventureeconomics.com/vcj/ protected/1070549855276.html>.

Trajtenberg. M. 1999. "Is Canada Missing the 'Technology Boat'? Evidence from Patent Data. CSLS-Industry Canada Conference on Canada in the 21st Century: A Time for Vision, September 17-18, 1999. Château Laurier Hotel, Ottawa, Ontario. Retrieved May 12, 2005. <www.csls.ca/events/sept1999/trajte.pdf>.

Valoir, T. "Government Funded Inventions: The Bayh-Dole Act and the Hopkins v. CellPro March-in Rights Controversy." <www.utexas.edu/law/journals/tiplj/volumes/vol8iss2/valoir.html>.

Weiss. 2004, September 24. Washington Post.

\section{About the Author}

Jeff Edelson, MD FRCPC, MHSc, is Vice-President Oncology Johnson \& Johnson Pharmaceutical Research and Development, Adjunct Associate Professor of Medicine, Department of Medicine, University of Pennsylvania and was previously Director of Research and Academic Affairs of the St. Michael's Hospital Health Sciences Research Centre, Toronto, Ontario.

Contact E-mail: jedelson@prdus.jnj.com 